\title{
Methodology of Law and Economics
}

\author{
Alessio M. Pacces ${ }^{*}$ and Louis Visscher ${ }^{* *}$ \\ 'What most distinguishes economics as a discipline from other disciplines in the social \\ sciences is not its subject matter but its approach'
}

Gary S. Becker

\section{Introduction}

A chapter on the methodology of law and economics, i.e. the economic analysis of law, concerns the methodology of economics. The above quote (Becker 1976, 5) shows that economics should not be defined by its subject, but by its method (also Veljanovski 2007, 19). This method forms the core of our contribution.

We discuss several related issues. In his entry on methodology in the Encyclopedia of Law and Economics, Kerkmeester (2000) states that most legal economists follow a pragmatic, eclectic approach and that it is hard to fit them in a particular school. A review of the methodology of law and economics must therefore concentrate on the ideas which are shared by the vast majority of legal economists (Kerkmeester 2000, 383). De Geest defines the use of elements from different schools as the 'integrated paradigm', and the predominant approach to law and economics as the 'mainstream approach' (De Geest 1994, 459ff, Mackaay 1991, p. 1509).

In law and economics, the economic approach operates on two distinct levels. First, human choice is analyzed from an economic point of view. The predominant approach here is the rational choice theory, which we discuss in Section 2. The basic idea of this theory is that human behaviour is analyzed as if people are seeking to maximize their expected utility.

The second level of the economic approach is the goals which are attributed to the legal system. In Section 3, we discuss the concept of market failure, which in law and economics is regarded as the primary raison d'être of law. Legal rules are analyzed as instruments to correct market failure, or at least to reduce its adverse consequences. We will briefly illustrate this idea by discussing, among others, competition law, tort law, patent law and consumer law as instruments to counter market power, negative externalities, collective goods and information asymmetry.

In Section 4, we discuss the Coase Theorem, which states that the allocation of legal entitlements between market players is irrelevant for efficiency when the parties can transact these entitlements costlessly. Given that transaction costs are positive in the real world, we also pay attention to their implications for regulation.

In Section 5, we discuss 'behavioural law and economics.' This relatively recent approach is based on insights from cognitive psychology, suggesting that people do not always act rationally. After reviewing the major findings in this field, we elaborate on the consequences for the more traditional approach of the rational choice theory.

In Section 6 we conclude.

\section{The Mainstream Economic Approach to Law}

\footnotetext{
Alessio M. Pacces is Associate Professor of Law and Economics at the Rotterdam Institute of Law and Economics, Erasmus School of Law, and Research Associate of the European Corporate Governance Institute.

Louis Visscher is Associate Professor of Law and Economics at the Rotterdam Institute of Law and Economics, Erasmus School of Law
} 


\subsection{Rationality}

Law and economics can be defined as the application of the rational choice approach to law (Kerkmeester 2000, 384; Ulen 2000, 797; Parisi 2004, 262). Under this approach it is assumed that people act rationally. A rational decision consists of three elements: (1) the actor chooses the option which (s)he thinks best meets his/her preferences, given his/her expectations; (2) his/her expectations are based on the information available to him/her, and (3) (s)he gathers an optimal amount of information (not too much and not too little). In short, the actors are assumed to maximize their expected utility. This expected utility is determined by multiplying the probabilities that the different outcomes will occur with the utility they yield if they materialize. The maximization of expected utility takes place under several constraints, such as income and time, but also cognitive resources which are discussed in more detail in Section 5 (Ulen 2000, 792).

The rational choice approach assumes that actors have transitive preferences, meaning that they can order them in the following sense: if the decision-maker prefers A over B and B over C, (s)he also prefers A over C. An additional assumption entails that the actor's preferences are stable over the period of analysis. This is not done out of a belief that preferences would not change, but because without this assumption one could always argue that if behaviour departs from the predictions, the preferences may have changed in the meantime (Becker 1976, 5; De Geest 1994, 424; Teijl and Holzhauer 1997, 40; Schäfer and Ott 2004, 53; Veljanovski 2007, 21).

The rational choice approach applies the principle of methodological individualism, implying that the basic unit of the analysis is the individual action. Collective phenomena and social interaction are therefore also explained in terms of decisions of individuals (Elster 1986, 3; Elster 1989, 13; De Geest 1994, 422; Kerkmeester 2000, 385; Mackaay 2000, 408; Schäfer and Ott 2004, 5).

Furthermore, rational choice theory assumes the existence of markets, which tend towards equilibrium. Prices or other instruments allocate the scarce resources (Becker 1976, 5; Mackaay 2000, 409). Ulen explains that legal rules often create implicit prices for different alternatives for behaviour. For example, tort damages, contract damages, administrative fines and criminal fines or jail sentences can be seen as the price to be paid for unlawful behaviour (Ulen 2000, 797). Economists generally argue that an increase in the price of a good or service leads, all else being equal, to a decrease in the demand of that good or service. The same idea can be applied to the implicit legal price, predicting a decrease in the unlawful behaviour if the price increases. The basic idea is that people respond to incentives and that price theory may prove beneficial in analyzing this behaviour (Korobkin and Ulen 2000, 1054).

The rational choice theory is outcome-oriented: in order to reach a goal, an actor employs the available means. This differs from e.g. the social norm theory, which is act-oriented: people act in a certain way because that is in line with the social norm. Furthermore, rational choice assumes that goals and means are independent of each other. Elster (1989) has shown that this is not always the case and that desires and opportunities can influence one another or can have a common cause. Due to space restrictions we will not further elaborate upon these interesting topics in this chapter. Kerkmeester (1992, 135 ff) and Kerkmeester (2000, 385ff) does it at length.

Rational choice theory does not claim to be able to predict all responses of all people under all circumstances. The assumption of rationality is, however, able to predict how some people - those who influence market outcomes (i.e., the marginal actors) - will respond. Rational choice allows generalizing statements regarding the likely effects of, among others, legal 
rules. If, for example, fines for speeding offenses increase, rational choice theory predicts a decrease in the number of speeding violations and/or in their severity, all else being equal. This does not mean that everyone will respond in this way to the increase, because the increased fine may still be inadequate to deter some people or they may not know about the increase in fines. However, as Veljanovski $(2007,23)$ puts it, 'criminals at the margin will be deterred by higher penalties; not the psychopath or deranged serial killer'. This implies that the response of a group can still be predicted, even though not all individual members in the group will respond in the same manner.

\subsection{The use of (sometimes unrealistic) assumptions}

Rational choice theory does not intend to provide a realistic description or explanation of human behaviour. Many of the assumptions made by rational choice theory are unrealistic in the sense that they do not correctly describe the actual decision-making process of individuals. If we, for example, have to choose in the supermarket between two substitute products (e.g. apple juice and orange juice), we simply choose the one we like best. We do not attach utility values to both products and subsequently maximize our expected utility by choosing the product with the highest value. However, our behaviour can be predicted and described as if we are doing exactly that. Such as-if-statements show that the rational choice theory is not concerned with a realistic description of behaviour.

The sometimes low level of realism of the assumptions which are used does not in itself jeopardize the usefulness of the rational choice theory, as long as one keeps in mind what theory wants to accomplish. If the theory is used to predict how people will respond to certain conditions, the relevant test of the theory does not lie at the level of the assumptions, but at the level of the predictions. If, on the other hand, one wants to understand why people respond the way they do, rational choice theory is less useful.

The assumptions made by economists are necessary for a tractable analysis of complicated issues. By focusing attention on the issue under investigation, thereby assuming away the issues which are not directly relevant for the analysis, it is easier to make general predictions. The fact that one has analyzed a 'simplified version of reality' is no problem, as long as this can still yield good predictions (Friedman 1953, 30ff; Rubin 1985; Kerkmeester 2000, 392; Posner 2003, 17ff). Friedman $(1953,21)$ provides the example of predicting the shots made by a billiard player. One can yield good predictions by assuming that the player makes mathematical calculations regarding the optimal speed, angle, rotation et cetera, even though in practice (s)he will not make these calculations. Coase objects to this approach and argues that a theory also serves as a base for thinking and 'helps us to understand what is going on by enabling us to organize our thoughts'. Realism in assumptions is needed to understand why a system works in the way it works (Coase 1994, 16ff).

In mainstream law and economics, the rational choice theory is not applied to understand human behaviour and the influence of law on it, but to predict the way in which people respond to the law. De Geest discusses the assumptions which are used and investigates whether they affect the plausibility of the theories. He argues that most assumptions are $a$ fortiori assumption (the conclusion becomes more plausible if the assumption is relaxed), black box assumptions (given the input one can calculate the output, even if one does not know the exact mechanism) or negligibility assumptions (which only have a negligible influence). Therefore, unrealistic assumptions often do not affect the plausibility of theories (De Geest 1994, 416ff and 436; De Geest 1996).

The rational choice theory is an example of a deductive approach: on the basis of (sometimes unrealistic) assumptions, hypotheses are derived which are subsequently tested empirically. 
Obviously, if unrealistic assumptions do not yield correct predictions, they should be changed, so that new hypotheses can be constructed, which again can be empirically tested. The main argument of behavioural law and economics challenges exactly the rationality assumption. This approach is inductive: in order to develop a theory, generalizations are made on the basis of empirical observations, (Kerkmeester 2000, 391).

\subsection{Positive and Normative Law and Economics}

Economic analysis of law can be performed in a positive and a normative way. A positive analysis provides statements of what the law and its effects are and it aims at explaining and predicting law and its consequences (Kerkmeester 2000, 390; Posner 2003, 24ff; Cooter and Ulen 2008, 3ff; Shavell 2004, 1ff). For example, Posner's 'efficiency theory of the common law' contends that the common law is best (although not perfectly) explained as a system for maximizing the wealth of a society (Posner 2003, 25).

The results of a positive analysis, i.e. predictions of how people will respond to different legal rules, open the discussion on what the law should be. A normative economic analysis therefore provides policy recommendations and is able to evaluate social policies.

Kerkmeester argues that it is difficult to strictly separate positive and normative analyses. The assumptions employed by the researcher in the positive analysis may already contain an implicit normative statement (Kerkmeester 1992, 127). He also refers to Coase's argument that economists are very well able to make value judgments, e.g. regarding a (positive) prediction that a certain measure (such as collectivization of agriculture) will lead to mass starvation (Coase 1994, 47). Predicting the consequences of alternative options would then almost automatically entail policy recommendations.

Normative law and economics is carried out as follows. Law is analyzed from an economic perspective, which, in mainstream law and economics, is the rational choice theory. Policy recommendations are derived on the basis of economic analysis. In order to be able to provide such recommendations, it is necessary to develop a framework for assessing the relative desirability of different outcomes. Law and economics crafts this framework around the notion of 'efficiency', meaning the maximization of social welfare (Teijl and Holzhauer 1997, 39ff; Posner and Parisi 1997, xi; Shavell 2004, 2; Schäfer and Ott 2004, 46ff; Parisi 2004, 262).

\subsection{Efficiency}

According to Schäfer and Ott $(2004,8)$, efficiency means that 'given the resources initially available and their allocation, the members of a society have achieved the highest possible level of utility.' In deciding which outcome out of several possibilities is socially preferable, the economic approach takes the perspective of the individual members of society. This approach is called methodological individualism. Social welfare is thus defined on the basis of the welfare of the individuals in society.

There are different approaches as to how to decide which of several options is preferable. The concept of 'Pareto efficiency' entails that a social state is efficient if it is no longer possible to make one person better off without making at least one person worse off. This concept is also known as 'allocative efficiency' (Schäfer and Ott 2004, 23; Parisi 2004, 266ff; Cooter and Ulen 2008, 17). The practical use of the Pareto principle is limited, because many policies will lead to some form of welfare redistribution in which some parties will be made worse off. For example, if a shift from negligence to strict liability would lead to a safer society 
because potential tortfeasors receive better behavioural incentives, while at the same time a higher proportion of the victims would receive more compensation with fewer efforts, the shift still would not be a Pareto improvement. After all, some injurers will now be liable where they would not have been under a regime of negligence.

Another limitation is that multiple Pareto-efficient situations are likely to exist, while the Pareto principle itself does not enable to choose between them. For instance, consider a 'society' consisting of three persons: A, B and C. Also consider four possible policies, which lead to the following distribution of welfare: I: A 100, B 100, C 100; II: A 110, B 100, C 100; III: A 120, B 110, C 90; IV: A 130, B 120, C 80. It is clear that state I is not Pareto efficient, because by choosing policy II it is possible to improve the situation of person A without worsening the situation of B and C. However, states II, III and IV are all Pareto efficient, because it is not possible to shift from one state to another without making at least one person worse off.

The aggregated welfare of A, B and C in the four possible states steadily increases, reaching its maximum in state IV. This could provide a guide in deciding which of the four possible scenarios is to be preferred. This is the essence of the alternative to Pareto efficiency: KaldorHicks efficiency. This criterion entails that a social state is efficient if it is no longer possible to increase the total welfare of a society. A change is hence regarded as an improvement if the persons who benefit from the change are able to compensate those who get worse off, and still they prefer the new situation to the old one (the criterion does not require actual compensation). A shift towards state IV in the above example is a Kaldor-Hicks improvement, because the gains of A and/or B are large enough to offset the loss of C, and still A and B together would benefit from the change. Only state IV is Kaldor-Hicks efficient. Kaldor-Hicks efficiency does not necessarily result in an equal distribution of welfare. After all, welfare is most equally distributed in state I, while the differences in individual welfare are the largest in state IV. In the economic analysis of law, maximization of total welfare is often taken as the predominant goal, while the distribution of welfare is regarded as of secondary importance. Moreover, redistribution should be aimed for with specific devices such as taxes and subsidies, not through e.g. private law (damages) and criminal or administrative law (fines) (Kaplow and Shavell 1994; Parisi 2004, 269; Shavell 2004, 647ff; Cooter and Ulen 2008, 9 ff).

In the economic analysis of law, the Kaldor-Hicks criterion is often chosen as the normative guideline to evaluate alternative policies. In other words, maximization of social welfare is regarded as the overall goal of law (Posner 2003, 24ff; Shavell 2004, 2; Schäfer and Ott 2004, 47). It is however important to devote specific attention to the question what exactly is maximized in the efficiency analysis.

\subsection{What is Maximized?}

There are different views on the measure to be applied in the maximization process. Kerkmeester (2000, 386ff) discusses two widely used measuring rods: money and utility. An advantage for using utility instead of money is that money 'suffers' from the problem of decreasing marginal utility of wealth. This means that the added value of an additional Euro in utility terms decreases as the amount of money one already has increases. After all, with the first Euros that someone earns, (s)he will satisfy the most urgent needs (food, clothing, housing). With subsequent Euros, less urgent needs will be satisfied, in the order of urgency. However, the degree in which marginal utility decreases may vary depending on the person and the situation. Maximizing an amount of money therefore does not necessarily maximize 
the utility of the people involved. In addition, it is very difficult, if not impossible, to make interpersonal comparisons of utility, because utility is subjective (Parisi 2004, 269). If the Pareto criterion was applied, there would be no need for such a comparison. But the limitations of this criterion have been already pointed out. The Kaldor-Hicks alternative does require a comparison of 'winners' and 'losers'.

Using a more objective standard such as money solves the problem of comparison. Even though it is not clear whether a Euro is worth more to one person than to another in utility terms, at least one could count the number of Euros of both persons and see when this amount is maximized. Posner has advocated 'wealth maximization' as the social goal: resources should end up with those who were willing and able to pay the highest amount (Posner 1985; Kerkmeester 2000, 387). Hence, willingness to pay and ability to pay are combined. It could be that a resource does not end up with the person with the highest willingness to pay, simply because (s)he is not able to pay that much. Wealth maximization therefore does not imply utility maximization (Calabresi 1980, 556). Note that Posner defines wealth as 'expected utility', so that it incorporates different risk attitudes (these attitudes show how uncertainty affects utility). Wealth differs from money in the sense that money is merely a measure of wealth (Posner 1985, 86ff).

There is no general consensus regarding which measure for social welfare is the best. It is not our intention to solve the debate on this issue. Both money and utility have their strong and weak points. Given that utility itself is a highly subjective measure which makes interpersonal comparisons (which are important in many legal settings) difficult or impossible and given that money often is an expression of the underlying utility values anyway, when we speak about 'maximizing social welfare', we refer to money as a measure. This does not mean that only financial interests can be included in the analysis. If we, for example, are willing to risk a speeding ticket in order to arrive in time for a concert, we value not missing part of the concert (on the basis of monetary and non-monetary considerations) more than the money value of the expected fine. In this way, money gives an observable expression of our subjective preferences. In other words, it shows our willingness to pay. The same line of reasoning holds for our willingness to risk liability when negligently causing losses or when not fulfilling our contractual duties, to risk criminal sanctions (financial or non-financial) when committing crimes, to bear the costs of a lawsuit when suing someone else, et cetera.

\section{Law as a Correction of Market Failure}

In this section, we describe the market form of full competition, in which maximization of social welfare is achieved. Subsequently, we discuss several departures from this standard (so-called 'market failures', see e.g. Rowley 1981, 401). Departure from the ideal model may imply failure to maximize social welfare. In the economic analysis of law, this is a reason for legal intervention.

\subsection{Full Competition: Maximization of Social Welfare}

In the model of full competition, social welfare is maximized. Transactions between many buyers and many sellers, who can freely enter or leave the market, occur without transaction costs on the basis of full information. Entitlements end up with the parties who value them the most. Actors incorporate all costs and benefits caused by their behaviour, both for themselves and for others. Hence, activities are only undertaken if the social costs are lower than the social benefits. The price of the products equals the full costs of production. Due to 
competition, producers are forced to produce efficiently, because consumers would otherwise buy the product from a cheaper, more efficient competitor.

Under these conditions, social welfare is maximized. This welfare is expressed as the sum of consumer surplus and producer surplus. These terms refer respectively to the difference between the maximum price consumers are willing to pay and the minimum price producers are willing to accept, and the market price which they actually pay or receive. If, for example, it costs an efficient producer 250 euro to produce a computer, I am willing to pay a maximum of 600 euro and the market price is 500 euro, the producer surplus equals 250 , the consumer surplus 100, and welfare increases by 350 euro due to the production and sale of this computer.

Full competition is a theoretical construction. In reality there will be departures from this ideal type, which result in a lower social welfare. In law and economics, law is analyzed as an instrument to cope with the negative consequences of such market failures.

\subsection{Market Power (Competition Law)}

Under full competition there are so many suppliers that none of them has the power to influence the market price. In situations where market power exists, the supplier(s) may decrease their output so that the market price increases, resulting in a higher price than would have occurred under full competition. This leads to a redistribution of wealth from consumers to producers, because the consumers who still buy the product now have to pay a higher price. More importantly, besides this redistribution effect there will also be a decrease in social welfare, because some consumers will no longer buy the product. Under full competition, all consumers who valued the product higher than the market price bought the product. The price increase due to market power will deter the consumers who value the product higher than the price under full competition, but lower than the price in case of market power. These forgone sales no longer result in consumer surplus or producer surplus. This welfare loss is called deadweight loss.

Market power causes other problems as well. First, there are costs attached to acquiring and maintaining market power. Second, producers with market power have fewer incentives to avoid inefficiencies in their production process, because they face less competition. Third, there are fewer incentives for innovation due to reduced competition, which may decrease the growth of welfare.

Competition law (antitrust law) can be regarded as a legal response to cure the inefficiencies arising out of this market failure. The prohibition of cartel agreements (Article 101 TFEU former Article 81 EC Treaty) and the ban on abuses of dominant position (Article 102 TFEU - former Article 82 EC Treaty) fit in this approach, although the way in which the European Commission interprets and applies these articles is not always consistent with economic insights (Van den Bergh and Camesasca 2006, 43ff). In situations where it is not possible or desirable to replace a monopoly, market power is allowed, but the ability of monopolists to set prices may be regulated to avoid or reduce the deadweight loss (Cooter and Ulen 2008, 43).

\subsection{Negative Externalities (Tort Law, Regulation and Criminal Law)}

The behaviour of one actor may have negative consequences for others, such as pollution, nuisance, and the creation of risks. If the actor who causes these negative consequences does not have to bear them, another market failure occurs because of negative externalities. As the 
actor does not bear the full social costs of his activities, but only the lower private costs, (s)he engages in the activity too often because that is basically too cheap. The correct activity level is determined by weighing the additional benefits as a result of an increase in the activity level against the additional social costs. As long as those benefits outweigh the costs, an increase in the activity level raises social welfare. However, due to the negative externality the actor engages in the activity as long as the additional private rather than social costs are lower than the additional benefits. Hence, an increase in the activity level may increase the private welfare of the actor, but it may decrease the social welfare due to the negative

consequences for others. Besides the problem of a too high activity level, the fact that part of the costs of the activity are borne by others than the actor himself may provide the latter with inadequate incentives to take precautionary measures, which could lower the probability of the negative consequences occurring and/or their severity.

Legal rules can be analyzed in their potential to make the injurer internalize the externality, so that the injurer bears the full costs of his behaviour. Regarding the example of pollution, through the use of tax law, the polluting activity can be made more expensive, so that is will be carried out less often. The tax could also induce measures which make the activity less polluting, if the tax is based on the level of pollution. Liability for environmental torts and penalties for environmental crimes could provide comparable incentives to socially optimal care and activity levels. Regulation could in detail prescribe which measures have to be taken to avoid or limit pollution, before a certain activity is granted the necessary permit.

The extensive literature on optimal enforcement analyzes the conditions under which public or private enforcement is better suited to providing the desirable incentives (see e.g. Landes and Posner 1975; Shavell 1984; Shavell 1993; Van den Bergh and Visscher 2008).

\subsection{Information as a Collective Good (Copyright and Patents)}

Collective goods are defined by their characteristics of non-exclusivity and non-rivalry. This means that it is not possible (or is too expensive) to exclude someone from enjoying the good and that the use of one person does not go at the expense of the possibilities for use of others. Due to these characteristics, producers cannot earn money with the production of a collective good, because potential users who are not willing to pay cannot be excluded, and their ability to use the good is not diminished by the use by others.

The archetypical Dutch example of a public good is a seawall. Everyone is equally protected against the water, whether (s)he has paid or not, and the protection of A does not go at the expense of the protection of B. This may induce free riding behaviour: if other people pay for the seawall, the non-paying free rider is also protected. If too many people behave as a free rider, there will not be enough resources collected to erect the seawall in the first place, which may lower social welfare. A solution is that the government produces the collective good and forces all people to contribute to it via compulsory taxes.

Information has the characteristics of a collective good, as soon as it is made publicly available: if one person has received the information others can still receive it as well, and excluding people who have not paid is often difficult, as shows from e.g. downloading of music and software and copying of texts.

The economic problem that occurs under these circumstances is that too little information is produced. If the producers of information (authors, musicians, inventors) cannot avoid the spread of their information after the initial publication, they will probably not be able to earn enough revenues to cover their production costs. For example, a pharmaceutical firm that has invested in the development of a new medicine wants to recover those costs and make some profits as well. A competing firm that buys the medicine on the market and applies reversed 
engineering is able to produce the same medicine and sell it for a much lower price, because it does not have to earn back the high development costs. If the original producer cannot act against this, it is likely that it will not develop the medicine in the first place, which may have severe consequences for social welfare.

The traditional solution for collective goods would entail that the government acts as producer of the information, e.g. through research in public universities or other governmental research organizations. Alternatively, research could be subsidized, e.g. through grants. In the case of information, intellectual property law is a possible solution. Through copyrights and patents, producers of information acquire a legal monopoly on the production and sale of the information. This enables them to earn money with their information after all, e.g. by marketing it themselves or by issuing licenses. However, this solution may itself cause subsequent welfare losses due to the market power which is created. The price of the protected information, such as the medicine from the example, may be higher than is necessary to earn back the development costs and a decent profit. This is an economic reason for the limited duration of patents.

\subsection{Information Asymmetry (Trademarks and Consumer Law)}

The information available differs between the parties to a transaction. For example, when principals cannot monitor their agents, the latter will tend to shirk, take excessive risks, or divert resources from the former. The problem, known as moral hazard (Arrow 1985), is particularly relevant in the context of insurance, banking, and corporate governance, and it is a major rationale for regulating these settings.

In addition, the problem of asymmetric information may result in adverse selection. As the seller of a good often knows more about its characteristics and its quality than the buyer, the following situation may occur: the buyer is willing to pay a higher price for a product of high quality, but (s)he cannot ascertain the quality of the product which is offered. The price (s)he is willing to pay under this uncertainty is lower than the seller of a high-quality product is willing to accept. Hence, welfare-increasing transactions may be foregone. The only sellers who accept the price offered by the buyer are those who know that their product is of lower quality. The buyer understands this and thus lowers the price (s)he is willing to pay. This negative spiral may lead to a situation where only low-quality products are offered. Akerlof (1970) described this situation as a 'market for lemons', where the 'lemons' are exemplified by low-quality second hand cars.

Trademarks may provide a solution to this problem. Through a trademark, producers or sellers of high quality products can provide information regarding the quality to the potential buyers. These buyers are willing to pay a higher price for these products, because they assess on the basis of the information provided by the trademark that the product is worth its higher price, e.g. because they have previous experience with these products or they know of experiences of others. In order for trademarks to be able to fulfil this function, infringements have to be deterred or sanctioned.

Consumer law may play a positive role too. For example, the seller may be subjected to the duty to convey information about the characteristics of the product. Furthermore, consumers may be enabled to act in situations where the product did not have the characteristics which they were reasonably allowed to expect, e.g. by being able to claim repair, replacement or damages.

\section{The Case for Regulatory Intervention and Its Limits}




\subsection{The Coase Theorem}

The presence of market failures is no sufficient ground for regulatory intervention. Under certain conditions, markets are self-correcting; and even when they are not, regulation provides no guarantee of a more efficient outcome. This proposition is based on the Coase Theorem, which is one cornerstone of the economic analysis of law.

The Coase Theorem (Coase 1960; Stigler 1966) states that the allocation of legal entitlements between market players is irrelevant for efficiency when the parties can transact these entitlements costlessly. In a frictionless world, where people bear no costs for finding, meeting, relying and concluding agreements with each other, the only assignment for the law would be to establish a system of property rights. If transacting is no scarce resource (i.e. transaction costs are zero), people would trade these entitlements until they are allocated to their best use and no further gains from trade are possible (i.e. allocation of all scarce resources within the economy is Pareto-efficient). It is easy to show that no market failure can persist in such a world.

Consider a factory polluting the neighbourhood with its smoke emissions (Veljanovsky 2007). This is apparently a negative externality. The Coase Theorem shows that there can be no negative externality in the absence of transaction costs. If the neighbourhood values the abatement of emissions more than emissions are worth to the factory, the smoke will be reduced anyway as contracting is costless: the neighbourhood would find it profitable to pay the factory a compensation for polluting less. This process will only stop when the marginal benefits of reduced smoke (for the neighbourhood) are equal to the marginal cost of abatement (for the factory). The efficient outcome does not depend on whether the factory has the right to pollute or the neighbours have the right to clean air. In the latter case, the factory will find it profitable to compensate the neighbourhood for allowing the emission of smoke. Again, the process will stop only when the marginal benefits of pollution (for the factory) are equal to the marginal costs of compensating the neighbourhood. Regardless of the rule of law, costless bargaining over clearly defined property rights leads anyway to the socially efficient outcome.

\subsection{Positive Transaction Costs}

The world of zero transaction costs does not exist, and even remote approximations of such a world are rare (think of how often small markets are established in a close neighbourhood). In spite of that, the power of the Coase Theorem is in its emphasis on transaction costs. Transaction costs explain a number of important real-world circumstances in which law 'matters' (La Porta et al. 1998), for the way in which it allocates entitlements between market players can increase or decrease the overall welfare of society.

The first thing law can do about transaction costs is to reduce the frictions that prevent private parties from capturing gains from trade (Cooter and Ulen 2008). There are significant costs of contracting, which are exemplified by the cost of legal counselling for the most complex transactions. The reason why we do not need to hire a lawyer for any contract we conclude is that contract law provides 'off-the-rack' default rules, which establish the terms of mutually beneficial exchanges in the vast majority of situations. Contract law also provides incentives to opt out of default rules when they are unsuitable for efficient bargaining. Of course, the cost of drafting alternative contract terms may prevent efficient transactions from going through. However, default rules still improve efficiency in this setting because they force the party dissatisfied with the standard term to reveal private information (Ayres and Gertner 
1989). Default rules thus reduce asymmetric information too, which is a major source of transaction costs (the cost of screening and monitoring counterparties).

Sometimes default rules are not enough to tackle transaction costs. As a result, market failure may occur because it would be simply too costly for private parties to overcome it. In those situations, law may seek to mimic the market outcome that would have occurred if transaction costs were lower. Law can assign a certain property right to the party or constituency that is most likely to value it the most. This solution is the more exposed to the risk of inefficient allocation the higher the transaction costs. Therefore, in situations where transaction costs are particularly high, liability rules are preferred (Calabresi and Melamed 1972). A liability rule enables one party to 'violate' the entitlement of potentially many counterparties by paying them compensation and without need to negotiate the transfer individually. In this case, the risk of inefficient resource allocation depends on the failure by courts or regulators to set compensation equal to the amount of the benefits foregone by the parties deprived of their entitlements.

These problems in attempting to solve market failures are illustrative of a more general implication of the Coase Theorem. In the world of positive transaction costs where we live in, it is extremely difficult for the law to outperform market outcomes. It might be tempting to consider regulation as a natural improvement of flawed market conditions. As this reasoning implicitly takes as benchmark an ideal of 'perfect market,' which is unattainable, it has been efficaciously characterized as 'nirvana economics' (Demsetz 1969). Markets may fail to deliver the efficient outcome because of high transaction costs; but so may regulation. There are three reasons for regulatory failure (Den Hertog 2000). First, regulation is costly, and its administrative costs may exceed the benefits of correcting market failures. Second, regulation can be mistaken, if only in those situations where regulators have less information than market players. Third, regulators are in principle as self-interested as market players, so they might be more concerned with maximizing their private utility than the welfare of society.

The fundamental lesson of the Coase Theorem is that efficient correction of market failures depends on a comparison of transaction costs (Eggertsson 1990). There are situations in which transaction costs are simply too high for markets to work efficiently. The provision of public goods (seawall, defence) and the prohibition of crime are prominent examples. Even in these domains, regulatory intervention is not efficient per se. Whether this is the case depends on its ability to minimize the transaction costs of dealing with monopolies, asymmetric information, and externalities relative to alternative arrangements (markets, firms, and other private or public institutions).

\section{Behavioural Law and Economics}

\subsection{The Limits of the Rationality Approach}

The Coase Theorem has been heavily debated (Schäfer and Ott 2004). One problem with Coase's analysis is that neither he enunciated the Theorem nor did he define transaction costs. As he made subsequently clear (Coase 1991), he wanted to point at transaction costs as a major subject of study in economics and the economic analysis of law. Transaction costs account for much more than the physical costs of contracting, as they include the costs of collecting information, of countering strategic behaviour, and of dealing with unforeseen contingencies (Allen 2000). This is still the domain of mainstream economic analysis of law. But the main criticism of the Coase Theorem is based on the implications of zero transaction costs. These implications hold so long as people are rational. But apparently, people cannot 
be credited to be such. As the Coase Theorem does not hold even in the absence of transaction costs, it cannot provide normative indications for the general case in which transaction costs are positive.

Behavioural law and economics has attempted to revisit economic analysis of law starting from the empirical falsification of the Coase Theorem (Jolls 2007). The Theorem does not hold when people are willing to pay less for acquiring a certain entitlement than they are willing to accept for giving up the same entitlement. This is known as 'endowment effect' and it has been tested successfully in a number of laboratory experiments replicating the conditions of zero transaction costs (Camerer and Talley 2007). Based on this result, and on the work of psychologists, behavioural law and economics contends that individuals are not rational - or at least not always - and therefore law has a larger role to play than simply coping with transaction costs.

Behavioural law and economics points to a number of individual biases in decision-making. For reason of space, we can only mention a few of them (see Jolls et al. 1998). For instance, individual choices are affected by framing: people are not indifferent between a 30\% probability of dying and a 70\% probability of living (they tend to choose the risky course of action when it is presented in the second fashion). Individuals also exhibit loss aversion: they value the chance of losing a certain amount of money more than the same chance of winning it. Individuals apparently also underestimate low-probability events, unless these events could result in dramatic harm to them, in which case the opposite is true. Finally, people tend to be overconfident in their own abilities, but they base their judgments on available heuristics, 'anchoring' their choices to the data that first come to their mind (for instance, people believe to be better drivers than average, but they are more prudent after having experienced or witnessed an accident). Besides these systematic errors of judgment, which are classified as 'bounded rationality,' behavioural law and economics also stresses 'bounded willpower' (the inability to stick to previous decisions, e.g. about healthy behaviour) and 'bounded selfinterest' (people tend to care of embedded notions of fairness, which implies more altruism than rational choice would predict).

The implication of behavioural law and economics is that the economic analysis of law cannot rely on the abstract notion of rational homo oeconomicus in analyzing market outcomes and the impact of legal rules thereon. This account is criticized on several grounds. First, the findings of behavioural law and economics are mostly based on experiments, and it is questioned that these experiments can replicate the conditions of real-world choices (Posner 1998). The argument applies even more forcefully to the results of surveys, as economists trust what people do, not what they say ('talk is cheap'). Second and relatedly, it is debatable that these findings invalidate rational choice. Economists infer rationality from a certain structure of preferences revealed by choice (Binmore 2007). Most of the above anomalies of choice could be reconciled with rationality under different specifications of preferences (including, for instance, limited knowledge or information about the alternatives). Third, behavioural law and economics is criticized for being a non-theory (Posner 1998). As it merely categorizes a number of empirical occurrences, it is not falsifiable. Conversely, rational choice is a fully-fledged theory. Its predictions are based on a unique set of assumptions and can be falsified by empirical evidence.

\subsection{The Contribution of Behavioural Insights to Law and Economics}

Short of the methodological criticisms, behavioural law and economics casts important doubts on the ability of individuals to cope with market failures. Not only does it reinforce 
the finding that transaction costs prevents people and societies from achieving efficient outcomes, but it also brings into question that individuals can care for their own good (Faure 2009). As such, behavioural law and economics seem to support an additional ground for regulatory intervention: paternalism. Under the assumption that people are not sufficiently rational to choose what is best for themselves (Korobkin and Ulen 2000), which implies a higher risk that they are taken advantage of in market interaction (Bar-Gill 2008), paternalistic regulation restricts the range of choices available to individuals.

Paternalism has important downsides. Not differently from regulations aimed at coping with market failures under rational choice, paternalism may result in greater harm than benefit to society. In addition to the ordinary reasons for regulatory failure, paternalism cannot be credited to be more rational than the poor choices it aims to rule out (e.g. Epstein 2008). In the absence of consistent indicators of individuals' preferences, paternalistic regulation can only guess what these preferences would be. As it disallows alternative preferences, or confines their revelation in illegal markets, paternalism of this kind subjects any improvement of market outcomes to extremely high transaction costs.

Acknowledging these drawbacks, some commentators argue in favour of a moderate form of paternalism. The basic idea of 'libertarian paternalism' (Thaler and Sunstein 2008) is to avoid restricting individual choices. However, when these choices are likely to be tainted by behavioural biases, libertarian paternalism would 'nudge' individuals towards a more rational behaviour. This is done mainly through default rules, as opting out of them prompts individual to consider their choice more carefully. The criticism to this solution is twofold. First, it is less neutral to individual choice than it looks (Zingales 2009). As the default rules set the stage of competition in the marketplace, individuals may have no access to alternative arrangements as they become too costly to supply (cheaper goods without warranties may become unavailable when warranty is the default and too few customers are willing to opt out of it). Second, also this mild form of paternalism deprives people of the incentive to improve the quality of their decision-making over time (Klick and Mitchell 2006). People who are less rational than they would like to be learn from past mistakes. By making mistakes less likely to occur, (libertarian) paternalism generates both cognitive and moral hazards. People need not think much when they are nudged into what is considered best for them (which implies that they may never discover what they actually want). And they may not worry much of the adverse consequences of departing from the default, as they can claim ex-post indemnification of the harm suffered on grounds that their choice was exactly the kind of irrational behaviour that regulation intended to avoid.

\section{Conclusion: Why is Law and Economics Useful to Lawyers?}

Economics is a social science studying human behaviour. The basic idea is that people respond to incentives, and then also to legal incentives. Rational choice theory provides a systematic framework with which predictions can be made regarding the way in which people will respond to legal intervention. It is therefore well suited to providing policy recommendations regarding the way in which social goals could be pursued.

The economic analysis of law regards maximization of social welfare as the overarching social goal. Different forms of market failures require different types of legal intervention. We have briefly discussed several areas of law in this light.

Even if a different social goal is chosen (for example, tort law may not be regarded as an instrument to provide deterrence to potential injurers, but as a way to compensate victims for unlawfully inflicted losses) the economic approach is still valuable, because it is able to provide predictions about whether these goals will be achieved. If, for example, victims do 
not initiate tort claims because this is too expensive, tort law will not be able to reach the compensation goal (as well as deterrence).

In the rational choice theory, predictions are made on the basis of assumptions regarding human behaviour. Behavioural law and economics questions some of these assumptions and points at a number of biases in decision-making. Here it is important to keep in mind what one wants to accomplish with the economic approach: explaining or predicting human behaviour? In our view, law and economics should provide policy recommendations on the basis of predictions on how people will respond to (legal) incentives. Which approach will be more successful in this respect is ultimately an empirical question.

Be this as it may, it is of utmost importance to study how people respond to economic and legal incentives in order to be able to assess which form of legal intervention is the best way to achieve certain goals. The outcome-oriented economic analysis of law has exactly this focus and is therefore very valuable to lawyers.

\section{Bibliography}

Akerlof, George (1970), 'The Market for Lemons: Qualitative Uncertainty and the Market Mechanism', Quarterly Journal of Economics, 84: 488-500.

Allen, Douglas W., (2000), 'Transaction Costs', in: Boudewijn Bouckaert and Gerrit De Geest (eds.), Encyclopedia of Law and Economics. Volume I. The History and Methodology of Law and Economics (Cheltenham: Edward Elgar), 893-926.

Ayres, Ian and Gertner, Robert E. (1989), 'Filling Gaps in Incomplete Contracts: An Economic Theory of Default Rules', Yale Law Journal, 99: 729-773.

Arrow, Kenneth J. (1985), 'The Economics of Agency', in J. Pratt and R. Zeckhauser (eds.), Principals and Agents: The Structure of Business (Harvard, MA: Harvard University Press), 37-51

Bar-Gill, Oren (2008), 'The Behavioral Economics of Consumer Contracts', Minnesota Law Review, 92: 749-802.

Becker, Gary S. (1976), The Economic Approach to Human Behavior (Chicago: The University of Chicago Press).

Binmore, Ken (2007), Playing for Real - A Text on Game Theory (Oxford: Oxford University Press).

Calabresi, Guido (1980), 'About Law and Economics: A Letter to Ronald Dworkin', Hofstra Law Review, 8: 553-562.

Calabresi, Guido and Melamed, A. Douglas (1972), 'Property Rules, Liability Rules, and Inalienability: One View of the Cathedral', Harvard Law Review, 85: 1089-1128.

Camerer, Colin and Talley, Eric (2007), 'Experimental Study of Law', in A. Mitchell Polinsky and Steven Shavell (eds.), Handbook of Law and Economics, II: 1619-1650 (Amsterdam: North Holland).

Coase, Ronald H. (1960), 'The Problem of Social Costs', Journal of Law and Economics, 3: $1-44$.

Coase, Ronald H. (1991), 'The Institutional Structure of Production', American Economic Review, 82: 713-719.

Coase, Ronald H. (1994), Essays on Economics and Economists (Chicago: University of Chicago Press).

Cooter, Robert D. (1984), 'Prices and Sanctions', Columbia Law Review, 84: 1523-1560.

Cooter, Robert D. and Ulen, Thomas S. (2008), Law and Economics, $5^{\text {th }}$ Edition (Boston: Pearson Addison Wesley). 
De Geest, Gerrit (1994), Economische analyse van het contracten-en quasi-contractenrecht. Een onderzoek naar de wetenschappelijke waarde van de rechtseconomie (Antwerpen: Maklu).

De Geest, Gerrit (1996), 'The debate on the scientific status of law \& economics', European Economic Review, 40: 999-1006.

Demsetz, Harold (1969), 'Information and Efficiency: Another Viewpoint', Journal of Law and Economics, 12: 1-22.

Den Hertog, Johan (2000), 'General Theories of Regulation', in: Boudewijn Bouckaert and Gerrit De Geest (eds.), Encyclopedia of Law and Economics. Volume V. Regulation of Contracts (Cheltenham: Edward Elgar), 223-270.

Eggertsson, Thráinn (1990), Economic Behavior and Institutions (Cambridge UK: Cambridge University Press).

Elster, Jon (1986), 'Introduction', in: Jon Elster (ed.), Rational Choice (Oxford: Basil Blackwell), 1-33.

Elster, Jon (1989), Nuts and Bots for the Social Sciences (Cambridge, Cambridge University Press).

Epstein, Richard A. (2008), 'The Neoclassical Economics of Consumer Contracts', Minnesota Law Review, 92: 803-835.

Faure, Michael G. (2009), 'The Impact of Behavioural Law and Economics on Accident Law' (Den Haag: Boom Juridische uitgevers).

Friedman, Milton (1953), 'The Methodology of Positive Economics', in Essays in Positive Economics (Chicago: University of Chicago Press), 3-43.

Jolls, Christine (2007), 'Behavioral Law and Economics', in Peter Diamond and Hannu Vartiainen (eds.), Behavioral Economics and Its Applications, 115-155 (Princeton: Princeton University Press).

Jolls, Christine, Sunstein, Cass R., and Thaler, Richard (1998), 'A Behavioral Approach to Law and Economics', Stanford Law Review, 50:1471-1550.

Kaplow, Louis and Shavell, Steven (1994), 'Why The Legal System is Less Efficient than the Income Tax in Redistributing Income', Journal of Legal Studies 23: 667-681.

Kerkmeester, Heico (2000), 'Methodology: General', in: Boudewijn Bouckaert and Gerrit De Geest (eds.), Encyclopedia of Law and Economics. Volume I. The History and Methodology of Law and Economics (Cheltenham: Edward Elgar), 383-401.

Klick Jonathan and Mitchell, Gregory (2006), 'Governemet Regulation of Irrationality: Moral and Cognitive Hazards', Minnesota Law Review, 90:1620-1663.

Korobkin, Russell B. and Ulen, Thomas S. (2000), 'Law and Behavioural Science: Removing the Rationality Assumption from Law and Economics', California Law Review 88: 10511144.

La Porta, Rafael, Lopez-de-Silanes, Florencio, Shleifer, Andrei and Vishny, Robert (1998), 'Law and Finance', Journal of Political Economy, 106: 1113-1155.

Landes, William M. and Posner, Richard A. (1975), 'The Private Enforcement of Law', Journal of Legal Studies, 4: 1-46.

Mackaay, Ejan (1991) 'Verschuivingen in de rechtseconomie', Nederlands Juristenblad 66: 1505-1521.

Mackaay, Ejan (2000), 'Schools: general', in: Boudewijn Bouckaert and Gerrit De Geest (eds.), Encyclopedia of Law and Economics. Volume I. The History and Methodology of Law and Economics (Cheltenham: Edward Elgar), 402-415.

Parisi, Francesco (2004), 'Positive, Normative and Functional Schools in Law and Economics', European Journal of Law and Economics, 18: 259-272.

Posner, Richard A. (1985), 'Wealth Maximization Revisited', Notre Dame Journal of Law, Ethics and Public Policy, 2: 85-105. 
Posner, Richard A. (1998), 'Rational Choice, Behavioral Economics, and the Law', Stanford Law Review, 50: 1551-1575.

Posner, Richard A. and Parisi, Francesco (1997), 'Introduction', in: Richard A. Posner and Francesco Parisi, Law and Economics Volume I - Theoretical and Methodological Foundations (Cheltenham: Edward Elgar), ix-li.

Posner, Richard A. (2003), Economic Analysis of Law, $6^{\text {th }}$ Edition (New York: Aspen Publishers).

Rowley, Charles K. (1981), 'Social Sciences and the Law: The Relevance of Economic Theories', Oxford Journal of Legal Studies, I: 391-405.

Rubin, Paul H. (1985), 'Some Notes on Methodology in Law and Economics', Research in Law and Economics, 7: 29-39.

Teijl, Rob and Holzhauer, Rudi W. (1997), Wisselende perspectieven in de rechtseconomie (Changing Perspectives in Law-and-Economics) (Arnhem: Gouda Quint).

Schäfer, Hans-Bernd and Ott, Claus (2004), The Economic Analysis of Civil Law (Cheltenham: Edward Elgar).

Shavell, Steven 91984), 'Liability for Harm Versus Regulation of Safety', Journal of Legal Studies, 13: 357-374.

Shavell, Steven (1993), 'The Optimal Structure of Law Enforcement', Journal of Law and Economics, 36: 255-287.

Shavell, Steven (2004), Foundations of Economic Analysis of Law (Cambridge, Massachusetts: The Belknap Press of Harvard University Press).

Stigler, George J. (1966), The Theory of Price ( $3^{\text {rd }}$ edn, New York: Macmillan).

Thaler, Richard H. and Sunstein, Cass R. (2008), Nudge - Improving Decisions about Health, Wealth, and Happiness (New Haven \& London: Yale University Press).

Ulen, Thomas S. (2000), 'Rational Choice Theory in Law and Economics', in: Boudewijn Bouckaert and Gerrit De Geest (eds.), Encyclopedia of Law and Economics. Volume I. The History and Methodology of Law and Economics (Cheltenham: Edward Elgar), 790818.

Van den Bergh, Roger J. and Camesasca, Peter D.N. (2006), European Competition Law and Economics: A Comparative Perspective (London: Sweet \& Maxwell).

Van den Bergh, Roger J. and Visscher, Louis T. (2008), 'Optimal Enforcement of Safety Law', in: Richard.V. de Mulder (ed.), Mitigating Risk in the Context of Safety and Security. How relevant is a Rational Approach? (Rotterdam: Erasmus University), 29-62.

Veljanovski, Cento G. (2007), Economic Principles of Law (Cambridge: Cambridge University Press).

Zingales, Luigi (2009), 'The Future of Securities Regulation', Journal of Accounting Research, 47: 391-426. 